\title{
Model of Punishment: Juvenile Justice Systems
}

\author{
Rafika Nur ${ }^{1}$ \\ Handar Subhandi Bakhtiar² \\ Nurul Miqat ${ }^{3}$ \\ Darmawati $^{4}$ \\ Mustawa $^{5}$ \\ ${ }^{1}$ Faculty of Law, Universitas Ichsan Gorontalo, Indonesia. E-mail: fikha.lecturer@gmail.com \\ ${ }^{2}$ Faculty of Law, Universitas Pembangunan Nasional Veteran Jakarta, Indonesia. E-mail: handar subhandi@yahoo.com \\ ${ }^{3}$ Faculty of Law, Universitas Tadulako, Indonesia. E-mail: nurulmiqat@gmail.com \\ ${ }^{4}$ Faculty of Law, Universitas Ichsan Gorontalo, Indonesia. E-mail: wati lecturer@yahoo.com \\ ${ }^{5}$ Faculty of Law, Universitas Bosowa, Indonesia. E-mail: mustawanur2@gmail.com
}

\section{Article Info}

Keywords:

Punishment;

Juvenile Justice System;

Children.

How to cite (APA Citation

Style):

Nur, R., et. Al. (2021).

"Model of Punishment:

Juvenile Justice Systems".

Jambura Law Review.

JALREV 3 Special Issue:

35-56

(C) 2021 - Nur, R., et. Al.

Under the license CC BY-SA 4.0

\begin{abstract}
The position of children who have special rights in the law makes children get special treatment. In the juvenile justice system in Indonesia, there are two systems of sanctions, namely criminal sanctions and actions, and this is done to realize the protection of children who are dealing with the law. This research is a normative juridical review, using a statute, comparative and conceptual approaches. The results show that the imposition of sanctions on children is based on the child's age, where children aged 12 to before 14 years can only be sanctioned with actions, and children aged 14 to before 18 years may be subject to criminal sanctions or actions.
\end{abstract}

\section{Introduction}

One of the law's goals is to realize the value of justice, for that law must reflect justice. Ideally, the process of law enforcement must uphold justice for everyone. To realize these national goals, national development efforts are needed, which include full human development. One such effort is development in the field of law, especially 
criminal law. ${ }^{1}$ Law cannot be seen as a final (finite scheme), but the law must continue to move, change and follow the dynamics of human life. Therefore, the law must be explored through progressive ${ }^{2}$ efforts, namely by presenting a breakthrough or improvement in the law itself can even change the totality of the legal system towards a better and truly to reach the truth and achieve the goal of justice.

In the context of criminal law enforcement, to achieve justice, one of them can be implemented by way of preventing and overcoming a crime that is part of a criminal policy. ${ }^{3}$ The policy was carried out using criminal law facilities (Penal Facilities), especially at the judicial policy stage (In-Abstracto), to the applicative and execution stages (In-Concreto Criminal Law Enforcement). Ideally, at each stage, attention must be paid to and lead to the achievement of the national goals of the Republic of Indonesia as stipulated in the Preamble of the 1945 Constitution of the Republic of Indonesia (NRI), namely to realize equitable justice for all Indonesian people.

The Indonesian Constitution provides guarantees for children's rights specifically as affirmed Article 28 B paragraph (2) of the 1945 Constitution of the Republic of Indonesia, which states, every child has the right to survival, growth, and development and is entitled to protection from violence and discrimination. Article 28 D paragraph (1) Every person has the right to recognition, guarantee, protection, and legal certainty that is and equal before the law. With this provision, the State must provide legal protection in the justice system, including the children of criminal offenses. ${ }^{4}$

Internationally, the principle of legal protection for children must be following the Convention on the Rights of the Child as ratified by the Government of the Republic of Indonesia with Presidential Decree No. 36 of 1990 concerning Ratification of the Convention on the Rights of the Child (Convention on the Rights of the Child).

\footnotetext{
1 Lili, R., \& Ira, R. (2001). "Dasar-Dasar Filsafat Hukum dan Teori Hukum". Bandung: Citra Aditya Bhakti.

2 Rahardjo, S. (2010). “Penegakan hukum progresif”. Jakarta: Penerbit Buku Kompas.

3 Ravena, H. D., \& SH, M. (2017). "Kebijakan Kriminal: [Criminal Policy]”. Jakarta: Penerbit Prenadamedia Group. p 3

${ }^{4}$ Wiyono, R. (2019). "Sistem Peradilan Pidana Anak di Indonesia". Retrieved from http://repo.iainbatusangkar.ac.id/xmlui/handle/123456789/11484. Accessed November 16, 2019
} 
Article 69 Paragraph (1) of Law No. 11 of 2012 concerning the Juvenile Justice System (in the future referred to as SPPA Law) determines: Children can only be sentenced to criminal or be subject to actions based on the provisions in this Law and paragraph (2) Children who have not 14 (fourteen) years old may only be subject to action. ${ }^{5}$

Article 70 and Article 82 of the SPPA Act for children are subject to sanctions based on "The mild conduct of the child, the personal condition of the child, or the condition when the act was committed or what happened then can be used as a basis for judges not to impose a criminal offense or impose an act by considering aspects of justice and humanity. "

Accountability for these children is also regulated in the Draft Penal Code in articles 110 to 128 relating to the minimum age for child criminal responsibility to formulate:

(1) Children who have not reached 12 (twelve) years who commit a crime cannot be accounted for.

(2) Criminal and acts for children only apply to persons aged 12 (twelve) years and 18 (eighteen) years who commit criminal acts.

The determination of the age of 12 years is also based on the Constitutional Court Decision No. 1 / PUU-VIII / 2010 which in its consideration states that it is necessary to set an age limit for children to protect children's constitutional rights, especially the right to protection and the right to grow and develop. ${ }^{6}$

The spirit of formal child protection has existed since the 1920s, starting with the Geneva Declaration (1923), which gave birth to Adoption Children's Rights guidelines. The configuration of the spirit of child protection was continued with implementing the United Nations Resolution (UN) Number: 40/33 of 1985 (popularly known as Convenant the Beijing Rules), which gave birth to guidelines for the establishment of the Juvenile Justice Administration. Then proceed with the United Nations Resolution (UN) Number: 45/112 of 1990 (popularly known as Convenant the Riyadh Guidelines), which subsequently gave birth to guidelines for the

5 Bakhtiar, H. S., Sofyan, A. M., \& Haeranah, H. (2019). "Criminal Justice System of Children in Indonesia". IOSR Journal Of Humanities And Social Science (IOSR-JHSS) 24 (1): 01-07.

${ }^{6}$ Nur, R., \& Bakhtiar, H. S. (2017). "Model of Child Prisoners Counseling (A Comparative Study in Japan, Malaysia and Indonesia". JL Pol'y \& Globalization, 68 (34). 
Prevention of Criminal Acts by Youth. Then the United Nations Resolution (UN) Number: 45/133 of 1990 (popularly known as Convenant Juveniles Deprived of Their Liberty) which later gave birth to guidelines on the Protection of Children who are being deprived of their liberty and The Tokyo Rules of 1990, which regulates Coaching Efforts in Outside the Institution.

Regarding sanctions for actions, Roeslan Saleh stated that if the criminal achieves the goal is not solely by imposing the crime, but it also uses action. So, in addition to the criminal sanctions, there are also actions. This is aimed solely at special prevention. This action aims to safeguard the security of the community against people who are a bit dangerous and will commit criminal acts. ${ }^{7}$

Sanction of actions aimed at the perpetrators of criminal acts based on protection so that the perpetrators of criminal acts will be better and not solely for retaliation. Actions are also oriented forward so that the perpetrators understand better that what was done is not right and violates the law not to repeat it one day. According to H.L. Packer on sanctions actions, "The Primary Purpose Of Treatment Is To Benefit The Person Being Treated. The Focus Is Not On His Conduct, Past Or Future, But On Helping Him. ${ }^{8}$

Substantially, the types of sanctions for action in the criminal law of children in Indonesia are still limited, both the type and variety of threats. Even systematics and types of actions are still simple. The dysfunction of supervising judges and observers regarding the supervision of the implementation of sanctions for actions against children is also evidence of an inadequate system of sanctions for actions against children. A series of mistakes by some judges in imposing sanctions on children can also be evidence of the imperfectness of the sanctions system of action in child criminal law in Indonesia. ${ }^{9}$

As formulated in the SPPA Law, the arrangement of the Two-Track System provides the choice for judges to impose sanctions on naughty offenders, namely criminal

\footnotetext{
7 Saleh, R. (1983). "Stelsel Pidana Indonesia". Jakarta: Aksara Baru. p. 9

${ }^{8}$ Packer, H. (1968). "The limits of the criminal sanction". California: Stanford University Press. p. 25.

${ }^{9}$ Sutatiek, S. (2013). "Rekonstruksi Sistem Sanksi dalam Hukum Pidana Anak di Indonesia". Sleman: Aswaja Pressindo p. 83
} 
sanctions or action sanctions. Critically, implementing the Double Track System as an effort made by the Indonesian government to find and determine other options besides criminal sanctions that will stigmatize ${ }^{10}$ children and effectiveness is considered relatively less effective in overcoming crime. According to Muladi, using a two-track system (Zweipurigkeit) as formulated in Article 22 of the SPPA Law. ${ }^{11}$

In the development of positive criminal law in Indonesia, sanctions have indeed been recognized in addition to criminal sanctions. Although the Criminal Code adheres to the Single Track System ${ }^{12}$ which only regulates one type, namely criminal sanctions (article 10 of the Criminal Code). The threat of sanctions Actions in the SPPA Act indicates that there are other means besides the criminal (penal) as a means of combating crime. Criminal sanctions emphasize the element of retaliation. The result is suffering internationally inflicted on an offender. At the same time, sanction for action stems from the basic idea of community protection and the formation or care of the maker or as J.E said. Jonkers, those criminal sanctions are emphasized on crimes that are applied for crimes committed, while sanctions actions have a social purpose..$^{13}$

\section{Problem Statement}

This paper will discuss the reconstruction of the regulation of the punishment of children through a comparative legal study in 2 countries, namely the Netherlands and Yugoslavia. In this paper, we will discuss the existence of overlapping norms, especially in regulating sanctions. Therefore, it is necessary to reconstruct the legal arrangement to provide clarity on the meaning and purpose of the regulation so that there will be no multiple interpretations in the application of the law.

\footnotetext{
10 Stigma is one of the negative consequences that arise with the imposition of imprisonment, which will carry over even if the person concerned no longer commits a crime, especially if the offender is a child. Arief, B. N. (1996). "Kebijakan legislatif dalam penanggulangan kejahatan dengan pidana penjara”. Badan Penerbit: Universitas Diponegoro. p. 48

11 Muladi, H. A. M. (2002). "Politik dan Sistem Peradilan Pidana". Semarang: Universitas Diponegoro, p. 156

12 Sholehuddin, M. (2003). "Sistem sanksi Dalam Hukum Pidana, Ide Dasar Double Track System \& Implementasinya". Jakarta: PT. RajaGrafindo Persada. p. 17

13 Jonkers, J. E. (1987). “Buku pedoman hukum pidana Hindia Belanda”. Jakarta: Bina Aksara. p. 350
} 


\section{Method/ Approach}

This research is a normative juridical review ${ }^{14}$, using a statute, comparative and conceptual approaches, namely by focusing its study by viewing law as a complete system, a set of legal principles and legal norms. The approach taken in this paper is a normative juridical approach that is by examining secondary data. ${ }^{15}$ The data have been collected and processed, subsequently performed classification using the method of interpretation and construction of laws is commonly used in the science of law and further qualitative juridical analysis. ${ }^{16}$

\section{The Age Limit for Children Can be Sanctioned}

The application of sanctions acts as sanctions against a crime based on several streams or opinions. First, Positive flow sees crime empirically by using scientific methods to confirm the facts on the ground with a crime. This flow is based on the understanding of determinism which states that a person commits a crime not based on will because humans do not have free will and are limited by various factors, personal character, biological factors, and environmental factors. Therefore, perpetrators of crimes cannot be blamed and convicted but must be given treatment (treatment) for resocialization and improvement of the perpetrators. ${ }^{17}$

Determinism is a philosophy that states that everything in this world, including humans, is determined by the law of cause and effect. ${ }^{18}$ Determinism states that human behavior is determined by factors that can be demonstrated. These factors include unconscious motives, childhood influences, hereditary influences, cultural influences, and so on. Second, a radical view was pioneered and defended by F. Gramatica, one of his writings entitled "the fight against punishment" (La Lotta Contra La Pena). Gramatika argues that "social protection law must replace the existing criminal law. The main purpose of the social protection law is to integrate the

\footnotetext{
14 Soekanto, S. (2006). "Pengantar penelitian hukum". Jakarta: UI Press, p.10

15 Soekanto, S., \& Mamudji, S. (2001). "Penelitian hukum normatif: Suatu tinjauan singkat”. Jakarta: Raja Grafindo Persada. p. 50-51

16 Ibid. p. 205-236

17 Lilly, J. R., Cullen, F. T., \& Ball, R. A. (2018). “Criminological theory: Context and consequences”. Sage publications, p. 22-24.

18 Harrison-Barbet, A. (1990). "Mastering philosophy". Macmillan International Higher Education, LondonL: The Macmillan Press Ltd. p. 326
} 
individual into the social order and not the punishment of his actions".19 Third, a moderate view is maintained by Marc Ancel (France), who instills the flow as Nouvelle Social Defense or New Social Defense or New Social Protection. According to Marc Ancel, each community requires a social order, a set of regulations that are not only following the need for a life together but also under the general public's aspirations. Therefore, a large role of criminal law is a necessity that cannot be put into a legal system. ${ }^{20}$

Regarding sanctions for actions, Roeslan Saleh stated that if the criminal in trying to achieve his goal is not solely by imposing a criminal, but in addition, it also uses action. So, in addition to the criminal sanctions, there are also actions. This is aimed solely at special prevention. This action aims to safeguard the security of the community against people who are a bit dangerous and will commit criminal acts. ${ }^{21}$

This flow of legal determinism considers that action for the offender is required by considering the psychological factor of the convicted person based on a psychiatric factor, namely belief in committing a crime. Therefore we need a process of soul rehabilitation called deradicalization. It is time for this policy to become a consideration in applying the criminal prosecution of child offenders.

Therefore, the Republic of Indonesia has constitutionally explicitly recognized, respected, and protected the constitutional rights of children, namely:

a. the right to survival;

b. the right to grow and develop, and;

c. the right to protection from violence and discrimination;

Recognition, respect, and guarantee as well as protection of the rights of the child referred to is the realization of the obligations of the state and at the same time the fulfillment of citizenship rights as a "granting of social rights to the people" (the granting of social rights).

\footnotetext{
${ }^{19}$ Muladi, \& Arief, B. N. (1984). "Teori-teori dan kebijakan pidana”. Bandung: Alumni. p. 35

${ }^{20}$ Ancel, M. (1998). "Social defence: A modern approach to criminal problems". London: Psychology Press. p.74

${ }^{21}$ Saleh, R, Op. Cit. p. 9.
} 
Children" are not "adults in a mini size" but "children" are subjects that are still vulnerable in the stages of evolving capacities, which are closely related to the causality between the fulfillment and protection of the right to life and the right of survival, the right to grow and develop children and the right to protection from violence and discrimination. So in the understanding of constitutional juridical, children's rights are not separated from one another, namely between the right to life and the right to survival, the right to grow and develop children, and the right to protection from violence and discrimination. In concrete circumstances, for example, disruption of growth and development of children who are imprisoned due to criminal decisions, then there is a constitutional loss of the child for survival and the right to grow and develop children, even though it is legal according to formal law. It needs to be emphasized that the right to life cannot be released with the right to survival and the right to growth and development, especially for children who are still in a period of growth and development, where every injury, destruction, or reduction of the child's survival rights will have serious and fatal consequences for the child's right to life.

Normatively, the criminalization of children constitutes an act that violates the constitutional right to protection and legal certainty that is fair and equal treatment before the law. Whereas based on Article 28D paragraph (1) of the 1945 Constitution, which states that, "Every person has the right to recognition, guarantees, protection and certainty of law that is just and equal treatment before the law". On that basis, the judges are encouraged to explore a sense of substantive justice (substantive justice) in the community rather than shackled by the provisions of the law (procedural justice)..$^{22}$

The basic idea of determinism philosophy: punishment emphasizes the values of humanity and education, in line with the nature of sanctions that emphasize that there should be no reproach of acts violated by the perpetrators. The theological basis, where the goal of punishment is educational, is to change the behavior of $A B H$

\footnotetext{
22 Moh. Mahfud MD, "Penegakan Keadilan di Pengadilan", an opinion on Harian Kompas, December 22, 2008, p. 6
} 
and others who tend to commit the crime. The purpose of education, social, prevention, recovery of certain circumstances, and non-repudiation.

Imposition of sanctions is one of the most difficult things that a judge must face in adjudicating a child case that conflicts with the law, especially a fair and appropriate sanction imposed on a child who has committed a crime. ${ }^{23}$

Indonesia ratified the International Convention on the Protection of Children beginning with Presidential Decree No. 36 of 1990 concerning the Ratification of the Convention on the Child's Rights. Seven years later, Law No. 3 of 1997 concerning Juvenile Court was later revised into Law No. 11 of 2012 concerning the juvenile justice system. This regulation is the beginning of the modernization of the Procedural Law for Children, where the sentence imposed on a child who commits a crime does not have to end in a Criminal Jail or the criminal impose on the Child (Actor) is the last place (Measure of the Last Resort), but instead, impose a sentence in the form of action return Children (Actors) to parents or submitted to Social Institutions for coaching.

Basic Philosophy that differs between Criminal Sanctions and Sanctions for Actions. There is a fundamental difference between criminal activity and that, in which Criminal Sanctions are for retaliation/reprisal for the mistakes of the makers. At the same time, the Actions are for the protection of the community and their makers' care. In other languages, the difference between the two can be seen from the basic idea, which is fundamentally different; namely, criminal sanctions are based on the basic idea "Why is punishment?"24 The sanction of action departs from the basic idea: "For what is punishment held?". Therefore, criminal sanctions are reactive to action, whereas sanctions are more of an anticipatory action against the perpetrators of those actions. If the focus of criminal sanctions is on one's actions through the imposition of suffering (so that the person concerned becomes a deterrent), the focus

23 Nur, R., \& Bakhtiar, H. S. (2020). The Imposition of Sanctions for Children. Hasanuddin Law Review, 6(2), 165-171.

${ }^{24}$ Nashriana, N. (2011). "Kritisi Terhadap Kebijakan Formulasi Sanksi Tindakan Bagi Anak Nakal Dilihat dari Perspektif Aliran/Mazhab Utilitis (Kemanfaatan)”. Simbur Cahaya. p. 30 
of sanctions is on helping change. ${ }^{25}$ The difference in orientation of the basic ideas of the two types of sanctions also has to do with the philosophical understanding that underlies them, namely the philosophy of indeterminism as a source of criminal sanctions and the philosophy of determinism as sources of action sanctions ${ }^{26}$. Therefore, when viewed from the perspective of the philosophy that sustains it, children who have committed delinquency must be based on the philosophy of determinism, although not in the extreme, because of the child's inability to take responsibility for what he has done. From the point of justification of punishment (justification of criminal punishment), the imposition of sanctions for children is included in the scope of behavioral understanding 27 (according to Packer) that is forward-looking (forward orientation). The criminal is not seen as retaliation to the criminal but rather is seen as a means to improve the offender's behavior because anti-social acts are committed outside the power of the individual itself.

Law No. 11 of 2012 concerning SPPA in Article 69 paragraph 2 states that:

Children who are not yet 14 (fourteen) years old may only be subject to action. If it is interpreted that this article limits the age of children who are not yet 14 years old, they can only be sanctioned by action, but on the one hand, Article 82 paragraph 3 states that:

The actions referred to in paragraph (1) may be filed by the Public Prosecutor in his claim unless the criminal act is threatened with imprisonment for a minimum of 7 (seven) years.

This Article has the meaning that sanctions in the form of returning to Parents / Guardians, surrender to someone, treatment in a mental hospital, treatment in LPKS, the obligation to attend formal education and or training conducted by the government or private bodies, revocation of driving licenses and or remedies due to

25 Ibid. p. 31

${ }^{26}$ Sholehuddin, M. Op. Cit. p. 32-33

27 Behavioral Understanding Is A Variation Of Classical Utilitarian Views. The Utilitarian View Sees the Falling of Sanctions in Terms of Purpose / Benefits / Their Use for Improvement and Prevention. See to Makarao, M. T. (2005). "Pembaharuan hukum pidana Indonesia: studi tentang bentuk-bentuk pidana khususnya pidana cambuk sebagai suatu bentuk pemidanaan". Yogyakarta: Kreasi Wacana. p. 32. 
criminal acts, all types of these actions can be handed down to children except for children who commit crimes that are punishable by imprisonment for a minimum of 7 years.

Unclear arrangements regarding the imposition of sanctions for actions can also be found in the general explanation of the SPPA Law, which states that:

Specifically, the sanctions for children are determined based on the difference in the age of the child, for children who are under 12 (twelve) years of age are only subject to action, whereas for children who have reached 12 (twelve) years of age up to 18 (eighteen) years old action and criminal can be sentenced.

The two articles each provide limits on the imposition of sanctions against children, but it can be contradictory. If, for example, a 13-year-old child commits a murder crime in which the criminal threat exceeds seven years, it will cause problems because one side of a child who is not yet 14 years old can only be sanctioned by action but if the threat of a crime committed by a child is more than seven years the child has a great chance of being given criminal sanctions.

Table 1

Article overlapping and resulting from Reconstruction

\begin{tabular}{|c|c|c|}
\hline $\begin{array}{c}\text { Article } 69 \\
\text { Paragraph } 2\end{array}$ & $\begin{array}{c}\text { Article } 82 \\
\text { Paragraph } 3\end{array}$ & $\begin{array}{c}\text { Reconstruction of } \\
\text { Article } 82 \\
\text { Paragraph } 3\end{array}$ \\
\hline $\begin{array}{l}\text { Children who are } \\
\text { not yet } 14 \\
\text { (fourteen) years old } \\
\text { may only be subject } \\
\text { to action }\end{array}$ & $\begin{array}{l}\text { The actions referred } \\
\text { to in paragraph (1) } \\
\text { may be filed by the } \\
\text { Public Prosecutor in } \\
\text { his claim, unless the } \\
\text { criminal act is } \\
\text { threatened with } \\
\text { imprisonment for a } \\
\text { minimum of } 7 \\
\text { (seven) years. }\end{array}$ & $\begin{array}{l}\text { The actions referred } \\
\text { to in paragraph (1) } \\
\text { must be submitted } \\
\text { by the public } \\
\text { prosecutor for } \\
\text { children aged } 12 \\
\text { years before before } \\
\text { the age of } 14 \text { years } \\
\text { and may be filed by } \\
\text { the public } \\
\text { prosecutor for } \\
\text { children who are } 14 \\
\text { years old and before } \\
18 \text { years. }\end{array}$ \\
\hline
\end{tabular}


Analysis of potential overlapping norms is part of the process of harmonization and synchronization of laws and regulations. At this stage, all laws and regulations which become the scope of activities will be analyzed to see the potential for overlapping existing regulations, both in one statutory regulation and between laws and regulations. The overlapping potential analysis carried out focuses on four aspects: 1) authority; 2) law enforcement; 3) protection; 4) rights and obligations, as a link for an assessment of harmonization and synchronization of regulations specifically related to the criminal law system of children.

Lon L. Fuller (1902-1978), a professor at Harvard University, asserted that positive law is obligatory in line with morality. Fuller is one of the figures in the legal school categorized as a positivism thinker, such as H.L.A. Hart, Dworkin, and Kelsen. Hart explained that the essence of law lies in the use of the element of coercion. Meanwhile, Lon Fuller emphasized the content of positive law. To recognize the law as a system, it must be observed whether it meets the following eight principles of legality:28

1) The legal system it must contain regulations meaning that it cannot contain merely ad hoc decisions;

2) The regulations that have been made must be announced;

3) Regulations cannot be retroactive;

4) The regulations are arranged in an understandable formula;

5) A system must not contain regulations that contradict each other;

6) The regulations must not contain demands that exceed what can be done;

7) Regulations should not be changed frequently;

8) There must be consistency between the promulgated regulations and their daily implementation.

Therefore, it is necessary to make changes to clarify the regulation of sanctions against children primarily in Article 69 paragraph 2 and Article 82 paragraph 3 of the SPPA Law in order to bring about justice and certainty. Imposing sanctions for actions must be based on the child's age where a child aged 12-14 years old

${ }^{28}$ Hart, H. L. A \& Green, L. (2012). The concept of law. United Kingdom: Oxford University Press. 
commits a criminal offense but cannot be convicted of a criminal offense but can only be subject to action sanctions. This threat consideration cannot be applied because it considers aspects of children's psychology that are still unstable and still need guidance in integrating with society.

The juvenile criminal justice system is still a derivative of the justice system for adults. This age difference can be legally responsible concerning the juvenile justice system implemented in these countries. Scotland does not have a special court for delinquent children because children who carry out delinquency are brought to an institution known as the Children's Hearing System that does not have the authority to impose sanctions to punish children. While in some countries the system of criminal punishment of children, sanctions or criminal threats and actions that can be imposed on children are:

Table 2

Comparison of Sanctions System for Children in Indonesia, the Netherlands and Yugoslavia

\begin{tabular}{|l|l|}
\hline Country & Types of Criminal sanctions / \\
Actions
\end{tabular}




\begin{tabular}{|c|c|c|}
\hline & $\begin{array}{l}\text { b. Submission to someone } \\
\text { c. treatment in a mental } \\
\text { hospital; } \\
\text { d. treatment at LPKS; } \\
\text { e. the obligation to attend formal } \\
\text { education and / or training } \\
\text { provided by the government } \\
\text { or private body; } \\
\text { f. revocation of driving license; } \\
\text { and } \\
\text { g. repairs due to criminal acts. } \\
\text { 4. The actions referred to in } \\
\text { paragraph (1) letter d, letter e, } \\
\text { and letter f are subject to a } \\
\text { maximum of } 1 \text { (one) year. }\end{array}$ & \\
\hline Netherlands & $\begin{array}{l}\text { Criminal subject (article } 77 \mathrm{~h} \\
\text { paragraph 1): } \\
\text { a. For crime } \\
\quad-\text { confinement of children; or } \\
\quad-\text { fine } \\
\text { b. For violations } \\
\quad-\text { fine } \\
\text { Substitute of principal crime } \\
\text { (article 77h paragraph (2)): } \\
\text { a. Social work or community } \\
\text { service } \\
\text { b. Work to repair damage } \\
\text { c. Following the training project } \\
\text { Additional crimes (article } 77 \mathrm{~h} \\
\text { paragraph (3)): } \\
\text { a. Deprivation; } \\
\text { b. SIM revocation } \\
\text { Actions (article } 77 \mathrm{~h} \text { paragraph } \\
\text { (4)): } \\
\text { a. Placement in special } \\
\text { institutions for children for } \\
\text { children; } \\
\text { b. Foreclosure; } \\
\text { c. Deprivation of profits from } \\
\text { acts against the law; } \\
\text { d. Compensation or } \\
\quad \text { compensation for damage / } \\
\text { loss }\end{array}$ & $\begin{array}{l}\text { Child confinement for a } \\
\text { minimum of } 1 \text { day a } \\
\text { maximum of } 12 \text { months for } \\
\text { children not yet } 16 \text { years old, } \\
\text { and a maximum of } 24 \text { months } \\
\text { for ages over } 16 \text { years } \\
\text { (article } 77 \mathrm{i} \text { ) } \\
\text { The amount of money as a } \\
\text { criminal fine is not less than } \\
\text { NGL } 5 \text { and not more than } \\
\text { NGL } 5000 \text { (Article } 77 \mathrm{j} \text { ) } \\
\text { The duration of social work } \\
\text { or the length of work to } \\
\text { repair the damage, may not } \\
\text { exceed } 200 \text { hours, the period } \\
\text { of work does not exceed } 6 \\
\text { months (article } 77 \mathrm{~m} \\
\text { paragraph (2) and paragraph } \\
\text { (3). training not more than } 6 \\
\text { months (article } 77 \mathrm{~m} \\
\text { paragraph (4) and paragraph } \\
\text { (5) Judges can drop after asking } \\
\text { opinion from the Board of } \\
\text { Trustees and child protection } \\
\text { (article } 77 \mathrm{n} \text { ) } \\
\text { Judge can drop after asking } \\
\text { opinion from the Board of } \\
\text { Trustees and child protection } \\
\text { (article } 77 \mathrm{n} \text { ) }\end{array}$ \\
\hline
\end{tabular}




\begin{tabular}{|c|c|c|}
\hline Yugoslavia & $\begin{array}{l}\text { Criminal subject (article 66): } \\
\text { a. juvenile prison } \\
\text { b. educative actions; and } \\
\text { c. security measures } \\
\text { Types of educative actions (article } \\
\text { 69): } \\
\text { a. disciplinary action ; } \\
\text { - warnings; } \\
\text { - put in a child disciplinary } \\
\quad \text { center intensive } \\
\quad \text { supervision measures } \\
\text { - } \text { supervision of parents / } \\
\quad \text { guardians } \\
\text { - supervision of other family } \\
\text { or trusteeship agencies } \\
\text { b. institutional measures } \\
\text { - placement of educational } \\
\quad \text { institutions; } \\
\text { - placement in Educational } \\
\quad \text { orphanages - corrective } \\
\text { - placement in handicapped } \\
\text { orphanages }\end{array}$ & $\begin{array}{l}\text { Junior children cannot be } \\
\text { convicted but may be subject } \\
\text { to educative action. Senior } \\
\text { children may be subject to } \\
\text { educational measures and } \\
\text { may be sentenced to juvenile } \\
\text { imprisonment. Safety } \\
\text { measures may be imposed } \\
\text { on senior children and junior } \\
\text { children (article } 66 \\
\text { paragraph (1), (2), (3). } \\
\text { Criminal imprisonment of a } \\
\text { child must not be less than } 1 \\
\text { year and more than } 10 \text { years } \\
\text { (article } 79 d) \\
\text { The purpose of this action is } \\
\text { to protect the education, } \\
\text { improvement and } \\
\text { development of child } \\
\text { offenders in order to expand } \\
\text { their protection, assistance } \\
\text { and supervision as well as to } \\
\text { prevent them from } \\
\text { committing criminal acts } \\
\text { (article } 68 \text { ) }\end{array}$ \\
\hline
\end{tabular}

Based on the above table, it can be illustrated that in the three countries, each has implemented two systems of sanctions against children, namely in the form of criminal sanctions and sanctions actions, with each country having differences in consideration in deciding the imposition of sanctions against children. However, it is clearly illustrated that age is a major consideration in deciding the imposition of sanctions on children.

Special in Indonesia itself The age limit of children is a consideration in imposing sanctions on children. To clarify the age regulation of children and the regulation of sanctions against children who commit criminal acts can be described in the following table: 
Table 3

Age Limit of Children and Criminal Liability for Children.

\begin{tabular}{|c|c|c|c|}
\hline Indicator & Age under 12 years & $\begin{array}{c}\text { Age } 12 \text { to before } 14 \\
\text { years }\end{array}$ & Age 14-18 years \\
\hline $\begin{array}{l}\text { Criminal } \\
\text { Liability }\end{array}$ & $\begin{array}{l}\text { Cannot Be Liable } \\
\text { (MK Decision No.1 / } \\
\text { PUU-VIII / 2010) }\end{array}$ & Can Be Responsible & Can Be Responsible \\
\hline $\begin{array}{l}\text { Decision/ } \\
\text { Sanction }\end{array}$ & $\begin{array}{l}\text { a. give it back to } \\
\text { Parents / } \\
\text { Guardians; or } \\
\text { b. include it in } \\
\text { education, } \\
\text { coaching and } \\
\text { mentoring } \\
\text { programs in } \\
\text { government } \\
\text { agencies or LPKS } \\
\text { in institutions } \\
\text { that deal with the } \\
\text { field of social } \\
\text { welfare, both at } \\
\text { the central and } \\
\text { regional levels, } \\
\text { for a maximum of } \\
6 \text { (six) months. }\end{array}$ & $\begin{array}{l}\text { Cannot be subject to } \\
\text { criminal sanctions, } \\
\text { may only be subject } \\
\text { to actions in the } \\
\text { form of: } \\
\text { a. returns to } \\
\text { parents / } \\
\text { guardians; } \\
\text { b. surrender to } \\
\text { someone; } \\
\text { c. treatment in a } \\
\text { mental hospital; } \\
\text { d. treatment at } \\
\text { LPKS; } \\
\text { e. the obligation to } \\
\text { attend formal } \\
\text { education and / } \\
\text { or training } \\
\text { provided by the } \\
\text { government or } \\
\text { private body; } \\
\text { f. revocation of } \\
\text { driving license; } \\
\text { and / or } \\
\text { g. repairs due to } \\
\text { criminal acts. }\end{array}$ & $\begin{array}{l}\text { May be subject to } \\
\text { criminal actions and } \\
\text { sanctions in the form } \\
\text { of: } \\
\text { 1. Principal crimes for } \\
\text { children consist of: } \\
\text { a. criminal } \\
\text { warning; } \\
\text { b. } \text { criminal with } \\
\text { the following } \\
\text { conditions: 1) } \\
\quad \text { guidance outside } \\
\text { the institution; } \\
\text { 2)community } \\
\text { service; or 3) } \\
\text { supervision. } \\
\text { c. } \text { work training; } \\
\text { d. coaching in } \\
\text { institutions; and } \\
\text { e. jail. } \\
\text { Additional crimes } \\
\text { consist of: } \\
\text { a. deprivation of } \\
\text { profits derived } \\
\text { from criminal } \\
\text { acts; or } \\
\text { b. fulfillment of } \\
\text { customary } \\
\text { obligations }\end{array}$ \\
\hline
\end{tabular}




\section{Classification of Crimes and Threats of Sanctions}

Jan Remmelink defines crime by starting a statement that to punish someone while fulfilling the demands of justice and humanity; there must be an act that is against the law and can be blamed on the culprit. Add to these conditions is that the person concerned must be someone who can be held responsible (toerekeningsvatbaar). ${ }^{29}$

Criminal, in essence, is a tool to achieve goals and how to formulate these objectives in the concept or material of a law which by its formers want to be enforced by including the criminal. In addition to being enforced, there are also objectives of criminalization and penal requirements. The purpose of punishment is the protection of society and the protection/coaching of individual perpetrators. Barda Nawawi Arief stated that the criminal is essentially only a tool to achieve the objectives that depart from the balance of two main objectives: the protection of society and the protection or coaching of individual perpetrators of criminal acts. ${ }^{30}$

The norms of criminal law and the threatening penal sanction norms in the Criminal Code are arranged systematically so that the relationship between criminal law norms in one article and another article is clear and how to formulate the threat of criminal sanctions. The recurring element is characteristic of codified law because it is prepared and prepared and formulated at the same time and by the same formulating institution.

The SPPA Law explains that children who are threatened with imprisonment for seven years or more may be subject to criminal sanctions, which can be in the form of imprisonment. In Book II of the Criminal Penal Code, Prison is used as a criminal threat 485 times and the penalty of imprisonment with a sentence of 7 years or more as many as 137 types of acts which can be described in detail as follows :

1) Treason $=15$ years - a lifetime - death;

\footnotetext{
${ }^{29}$ Remmelink, J., \& Moeliono, T. P. (2003). "Hukum pidana: komentar atas pasal-pasal terpenting dari kitab undang-undang hukum pidana belanda dan padanannya dalam kitab undang-undang hukum pidana indonesia". Jakarta: Gramedia Pustaka Utama. p. 85

${ }^{30}$ Nawawi, A. B. (2002). "Bunga Rampai Kebijakan Hukum Pidana: Edisi Revisi”. Bandung: PT. Citra Aditya Bakti, p. 88.
} 
2) Rebellion = 15 years;

3) Dissolution of the official state meeting = 9 years;

4) Criminal acts of statements of hostility, hatred, or degrading the government $=6$ months -7 years;

5) Crime that endangers public security (burning, blowing up) = 12 years - for life;

6) Perjury or false confinement = 7 years;

7) Counterfeiting of currency and banknotes = 15 years;

8) Falsification of stamp duty and brand = 7 years;

9) Rape $=9$ years;

10) Forced sexual immorality = 9 years;

11) Criminal acts against freedom of persons (slavery) = 12 years;

12) Crime against life $=15$ years - a lifetime - death;

13) Persecution resulting in death or serious injury $=7$ years

14) Theft with qualifications $=7$ years

15) Criminal offenses (abuse of authority) $=7$ years.

Based on the above classification, according to the author, it can be classified as a threat of a sentence of 7 years or more carried out by children over the age of 14 years and before the age of 18 years may be subject to criminal sanctions or actions namely:

1) Rape Crimes

2) Criminal Actions Forced to Perform Obscenity

3) Criminal Acts against Life

4) Criminal offenses that cause death or serious injury

5) Theft with Qualifications

According to the authors of some of the above criminal offenses, several offenses can be carried out by a child who is threatened with a sentence of 7 years or more can wear an action in which the child commits the crime aged 12 and before the age of 14 years, but if the crime is conducted by children aged 14 years and before the age of 18 years may be subject to action or criminal sanctions. The author's consideration that a child who is 12 years old and before 14 years cannot be convicted at all but can only 
be subject to action even if the child's actions are threatened with a sentence of 7 years or more.

The Draft Book of the Criminal Code Book 1 of Article 113 Paragraph 3 states that a child under the age of 14 cannot be convicted of a crime and can only be subject to action. This is consistent with the formulation of the concept from the author that children can only be subject to action if they are not yet 14 years old. This is because the aspect of protection for children is the main reason it cannot be categorized to qualify the act as the basis for the fall of the action to the child and, more specifically, to the child's future development later. Having found that events early in a person's life may be related to subsequent behavior, the report goes on to consider the role of early experiences with parents and family with subsequent criminal behavior. Children whom their parents reject, grow up in homes with significant conflict, and are inadequately supervised are at the greatest risk of becoming criminals. There appears to be a cumulative effect such that the presence of more than one of these negative family attributes further increases the likelihood of crime. Not all children follow the same path to crime; Different combinations of life experiences can produce criminal behavior. Positive parenting practices in the early years and later in adolescence seem to act as buffers that prevent criminal behavior and help young people already involved in such behavior by refraining from further crime.

Research confirms that children who grow up in supportive, loving, and accepting homes are less likely to become deviant. Children whom their parents reject are among the most likely to become criminals. Studies also show that the child's disposition plays a role in this causal chain. An awkward child or teenager is more likely to be rejected by the parents, creating an escalating cycle that can lead to crime. Marital discord and conflict, and child abuse are linked to the crime. Not all children who grow up in conflicting or violent homes become criminals; However, exposure to conflict and violence increases the risk of crime.

A child with criminal parents is more likely to become a criminal than children with law-abiding parents. However, the influence does not seem to be directly related to crime but rather to poor supervision. Studies show that positive parenting, including 
normative development, supervision, and discipline, clearly affects whether children become criminals. Adequate supervision of leisure activities, residences, and peers is essential to ensure that children do not run into antisocial and criminal behavior patterns. Surprisingly, not much is known about normative and moral development within the family related to crime. Also, according to the author, in imposing sanctions on children, they must avoid children from imposing criminal sanctions and prioritizing child development by presenting the state as the party responsible for guiding children through a system of childcare that is schematized so that children can become better than previous actions and can prevent children from committing criminal acts in the future.

\section{Conclusion}

The model of punishment in the juvenile justice system based on the aspect of expediency lies in arrangements related to the age limit of children who are only subject to action at the age of 12 years before the age of 14 years and cannot be convicted of a crime even though the child commits a crime that is threatened with sanctions imprisonment seven years or more and to children aged 14 years before 18 years can be sentenced to a criminal or act with consideration of looking at the state of the child at the time of the crime and the impact resulting from the crime.

\section{References}

Arief, B. N. (1996). Kebijakan legislatif dalam penanggulangan kejahatan dengan pidana penjara. Badan Penerbit: Universitas Diponegoro.

Ancel, M. (1998). Social defence: A modern approach to criminal problems. London: Psychology Press.

Bakhtiar, H. S., Sofyan, A. M., \& Haeranah, H. (2019). Criminal Justice System of Children in Indonesia. IOSR Journal Of Humanities And Social Science (IOSR-JHSS) Volume, 24, 01-07.

Bakhtiar, H. S. (2015). Penerapan Sanksi Pidana dan Tindakan Terhadap Anak Menurut UU No.11 Tahun 2012 Tentang Sistem Peradilan Pidana Anak. Universitas Muslim Indonesia.

Hart, H. L. A \& Green, L. (2012). The concept of law. United Kingdom: Oxford University Press. 
Harrison-Barbet, A. (1990). Mastering philosophy. Macmillan International Higher Education, London: The Macmillan Press Ltd.

Jonkers, J. E. (1987). Buku pedoman hukum pidana Hindia Belanda. Jakarta: Bina Aksara.

Lili, R., \& Ira, R. (2001). Dasar-Dasar Filsafat Hukum dan Teori Hukum. Bandung: Citra Aditya Bhakti.

Lilly, J. R., Cullen, F. T., \& Ball, R. A. (2018). Criminological theory: Context and consequences. Sage publications,

Makarao, M. T. (2005). Pembaharuan hukum pidana Indonesia: studi tentang bentukbentuk pidana khususnya pidana cambuk sebagai suatu bentuk pemidanaan. Yogyakarta: Kreasi Wacana.

Muladi, H. A. M. (2002). Politik dan Sistem Peradilan Pidana. Semarang: Universitas Diponegoro.

Muladi, \& Arief, B. N. (1984). Teori-teori dan kebijakan pidana. Bandung: Alumni.

Moh. Mahfud MD, "Penegakan Keadilan di Pengadilan", Opini di harian Kompas, 22 Desember 2008,

Nashriana, N. (2011). Kritisi Terhadap Kebijakan Formulasi Sanksi Tindakan Bagi Anak Nakal Dilihat dari Perspektif Aliran/Mazhab Utilitis (Kemanfaatan). Simbur Cahaya.

Nawawi, A. B. (2002). Bunga Rampai Kebijakan Hukum Pidana: Edisi Revisi, Bandung: PT. Citra Aditya Bakti.

Nur, R., \& Bakhtiar, H. S. (2020). The Imposition of Sanctions for Children. Hasanuddin Law Review, 6(2), 165-171.

Nur, R., \& Bakhtiar, H. S. (2017). Model of Child Prisoners Counseling (A Comparative Study in Japan, Malaysia and Indonesia. JL Pol'y \& Globalization, Vol. 68, 34.

Packer, H. (1968). The limits of the criminal sanction. California: Stanford University Press Rahardjo, S. (2010). Penegakan hukum progresif. Jakarta: Penerbit Buku Kompas.

Ravena, H. D., \& SH, M. (2017). Kebijakan Kriminal:[Criminal Policy]. Jakarta. Penerbit Prenadamedia Group.

Remmelink, J., \& Moeliono, T. P. (2003). Hukum pidana: komentar atas pasal-pasal terpenting dari kitab undang-undang hukum pidana belanda dan padanannya dalam kitab undang-undang hukum pidana indonesia. Jakarta: Gramedia Pustaka Utama.

Saleh, R. (1983). Stelsel Pidana Indonesia, Jakarta: Aksara Baru.

Sholehuddin, M. (2003). Sistem sanksi Dalam Hukum Pidana, Ide Dasar Double Track System \& Implementasinya, Jakarta: PT. RajaGrafindo Persada.

Soekanto, S. (2006). Pengantar penelitian hukum, Jakarta: UI Press.

Soekanto, S., \& Mamudji, S. (2001). Penelitian hukum normatif: Suatu tinjauan singkat. Jakarta: Raja Grafindo Persada. 
Sutatiek, S. (2013). Rekonstruksi Sistem Sanksi dalam Hukum Pidana Anak di Indonesia. Sleman Aswaja Pressindo.

Wiyono, R. (2019). Sistem Peradilan Pidana Anak di Indonesia. Retrieved from http://repo.iainbatusangkar.ac.id/xmlui/handle/123456789/11484 . Accessed November 16, 2019 